\title{
Geologi dan Petrokimia Endapan Zeolit Daerah Bayah dan Sukabumi
}

\author{
Iwan Setiawan ${ }^{1 *}$, Lenny M. Estiaty ${ }^{1}$, Dewi Fatimah ${ }^{1}$, Sri Indarto ${ }^{1}$, Lediyantje \\ Lintjewas $^{1}$, Andri Alkausar ${ }^{1}$, Aryo D. Handoko ${ }^{1}$, Anita Yuliyanti ${ }^{1}$, dan \\ Jakah $^{1}$
}

${ }^{1}$ Pusat Penelitian Geoteknologi, Lembaga Ilmu Pengetahuan Indonesia (LIPI), Bandung

\begin{abstract}
ABSTRAK Zeolit dijumpai pada batuan piroklastik di daerah Cikembar (Sukabumi) dan Bayah (Banten) dari zona fisiografi pegunungan Bogor dan Bayah. Karakteristik, genesa batuan, dan tipe zeolit di kedua lokasi tersebut belum dijelaskan, terutama kaitannya dengan potensi pengkayaan unsur tanah jarang (UTJ) pada batupasir tufan di daerah Cikembar dan tuf teralterasi di daerah Swakan. Metode yang digunakan pada studi ini terdiri dari pengamatan geologi lapangan, petrografi, difraksi sinar-X (XRD), dan kimia batuan (whole rock) menggunakan XRF dan ICP-MS. Tujuannya adalah untuk mengungkap genesa pembentukkan zeolit dan UTJ di Swakan dan Cikembar. Batupasir tufan dari Cikembar dan tuf dari Swakan menunjukkan kehadiran zeolit bertipe mordenit dan klinoptilolit. Zeolit di daerah Cikembar terdapat sejajar perlapisan, sedangkan di daerah Swakan berasosiasi dengan kumpulan mineral alterasi. Pengendapan zeolit Cikembar dipengaruhi oleh air meteorik yang dicirikan oleh anomali negatif Ce pada pola diagram laba-laba yang di normalisasi terhadap kondrit. Total ( $\sum$ UTJ) pada batupasir tufan dari Cikembar 8294 ppm dan pada tuf Swakan 71-83 ppm. Perbedaan kandungan $\sum$ UTJ tersebut lebih mencerminkan komposisi UTJ pada batuan asal.
\end{abstract}

\footnotetext{
Naskah masuk : 10 April 2019

Naskah direvisi : 10 April 2020

Naskah diterima : 10 April 2020
}

*Penulis korespondensi.

Email: bogalakon@gmail.com
Kata kunci: zeolit, Jawa Barat, mordenit dan klinoptilolit, unsur tanah jarang (UTJ)

ABSTRACT - Geology and petrochemistry of zeolite deposits of Bayah and Sukabumi areas. Zeolites are found in pyroclastic rocks in Cikembar (Sukabumi) and Bayah (Banten) from the Bogor and Bayah mountainous physiographic zones. The characteristics, rock genesis, and types of zeolites from these two locations have not been explained, especially in relation to the potential of REEs (Rare Earth Elements) enrichment in Cikembar tuffaceous sandstone and Swakan altered tuff. The method used in this study consists of field geological observations, petrography, $X$ ray diffraction (XRD), and whole rock geochemistry using XRF and ICP-MS. The aim is to uncover the formation of zeolites and REEs in Swakan and Cikembar.The Cikembar tuffaceous sandstones and the Swakan tuffs show the presence of mordenite and clinoptilolite types of zeolites minerals. The zeolites in Cikembar area are parallel to the bedding plane, while in Swakan area are associated with alteration mineral assemblages. The deposition of Cikembar zeolite was influenced by meteoric water which is characterized by the negative Ce anomalies in chondrite-normalized spider diagram pattern. The total ( $\left.\sum R E E s\right)$ concentration in Cikembar tuffaceous sandstones are 82-94 ppm and Swakan tuffs are 71-83 ppm. The difference in the $\sum R E E$ content more likely reflects the parent's rock REEs composition.

Keywords: Zeolite, West Java, mordenite and clinoptilolite, rare earth elements (REE) 


\section{PENDAHULUAN}

Zeolit secara umum merupakan material kristalin yang terbentuk di alam, berkomposisi hidro alumino-silikat dengan ikatan alkali atau alkali tanah lemah, serta memiliki struktur tetrahedra. Masing-masing struktur tersebut memiliki empat atom yang dikelilingi oleh kation. Pada kerangka seperti ini terdapat saluran atau lorong yang biasa diisi oleh molekul $\mathrm{H}_{2} \mathrm{O}$ atau kation lainnya yang biasa saling bergantian, bertukar kation, mengakibatkan zeolit sangat efektif sebagai penukar kation (Duplouy 2016; Rodiana, 2016; Kusdarto 2008; Kanazawa and Kamitani 2006; Coombs et al., 1997). Zeolit merupakan bahan galian non logam atau mineral industri multi guna karena memiliki sifat-sifat fisika dan kimia yang unik, diantaranya yaitu sebagai makanan dan obatobatan, penyerap, penukar ion, penyaring molekul, pembuatan pupuk, penghilang bau, penjernih air, dan lain-lain (Rodiana, 2016; Karakaya et al., 2015).

Zeolit terdiri dari paling tidak 46-50 spesies yang berbeda (Gottardi and Galli, 1985; Kusdarto, 2008). Namun yang paling umum dijumpai di Indonesia adalah analsim, khabasit, klinoptilolit, heulandit, erionit, ferierit, laumontit, mordenit dan filipsit (Kusdarto, 2008). Di antara jenis mineral zeolit tersebut, mordenit dan klinoptilolit adalah yang paling sering teridentifikasi pada endapan zeolit di Jawa Barat.

Mordenit adalah mineral zeolit kaya silika yang berasosiasi dengan heulandit sebagai hasil dari alterasi batuan vulkaniklastik (Kitsopoulos, 1997). Ketika zeolit terbentuk dari hasil hidrasi, penguraian gelas vulkanik dan aktifitas fluida di dalam pori batuan, maka mineral heulandit akan terbentuk dengan sedikit mineral mordenit (Kitsopoulos, 1997). Mordenit dapat juga terbentuk dari gelas vulkanik berkomposisi riolitik, sedangkan khabazit, filipsit, dan analsim dari gelas vulkanik berkomposisi phonolitik ( $\mathrm{pH}$ sampai mendekati 9,5) dan dari gelas vulkanik berkomposisi basaltik (Holler and Wirsching, 1978). Klinoptilolit dapat dijumpai berhubungan dengan gelas vulkanik berkomposisi asam dalam batuan piroklastik tuf gelas (vitric tuff) dan sedimen mengandung gelas vulkanik karena proses diagenesa, khususnya yang mengalami sedimentasi cepat (Iijima, 1980).

Proses hidrotermal dan zeolit pada beberapa kasus berhubungan dengan potensi unsur tanah jarang
(UTJ). Kehadiran unsur tanah jarang (UTJ) pada beberapa tipe zeolit terjadi karena kemampuan bertukar ion UTJ dengan jenis zeolit Lindle tipe L (LTL) (Duplouy, 2016) dan klinoptilolit (Vasylechko et al., 2013). Kemampuanya dalam bertukar ion menjadikan zeolit berpeluang untuk dimanfaatkan dalam pemisahan UTJ (Duplouy, 2016). UTJ adalah sekumpulan unsur-unsur pada grup lanthanoids dengan tambahan yttrium dan scandium. UTJ dikelompokkan menjadi unsur Light Rare Earth Elements (LREE) terdiri dari La, $\mathrm{Ce}, \mathrm{Pr}, \mathrm{Nd}, \mathrm{Pm}, \mathrm{Sm}, \mathrm{Eu}$ dan Gd dan Heavy Rare Earth Elements (HREE) terdiri dari Y, Tb, Dy, Ho, $\mathrm{Er}, \mathrm{Tm}, \mathrm{Yb}$, dan Lu ( Dickson, 2015; Connelly et al., 2005).

Kebutuhan zeolit semakin meningkat, sementara zeolit yang berkualitas baik sudah semakin berkurang. Begitupula dengan cadangan zeolit di Indonesia. Pemahaman geologi mengenai keterdapatan zeolit dapat menunjang penemuan endapan zeolit baru di daerah lainnya di Indonesia. Dengan ditemukannya endapan zeolit yang baru, maka akan membantu membangun industri, ekonomi kreatif, dan menyerap tenaga kerja. Tulisan ini bertujuan untuk mengungkap genesa endapan zeolit berdasarkan karakter kimia dan mineralogi. Keterdapatan zeolit di daerah penelitian akan dianalisis hubungannya dengan kandungan unsur tanah jarang pada batuan asalnya. Lokasi penelitian berada di daerah daerah Swakan, Lebak (Bayah), Provinsi Banten dan Cikembar (Sukabumi), Provinsi Jawa Barat (Gambar 1).

\section{TATANAN GEOLOGI}

\section{Geologi dan Genesa Endapan Zeolit}

Pulau Jawa merupakan bagian dari sistem busur magmatik Sunda yang terbentuk akibat subduksi lempeng Indo-Australia ke bawah Lempeng Eurasia (Dempsey, 2013; Hall 2012; 1996). Subduksi terjadi sejak jaman Eosen menghasilkan rangkaian busur magmatik berupa batuan sebaran batuan vulkano-plutonik yang berasosiasi dengan endapan logam maupun non logam. Keterdapatan mineral zeolit umumnya berhubungan erat dengan aktivitas vulkanik berupa batuan-batuan piroklastik kaya gelas vulkanik (vitric tuff) yang teralterasi oleh proses hidrotermal (Kusdarto, 2008), dan atau proses sedimentasi dan pembebanan (diagenesis) (Iijima, 1980). 
Indonesia disusun oleh rangkaian gunungapi yang produk letusannya tersebar luas dan disebutkan memiliki potensi sumberdaya endapan zeolit sebesar 447.490 ton. Penyebaran paling luas terdapat di Jawa Barat, Banten, Lampung, Sulawesi Selatan, Nusa Tenggara Timur, dan Tapanuli Utara (Kusdarto, 2008). Dua lokasi yang memiliki sumberdaya zeolit terbesar terdapat di Sangkaropi (Tana Toraja) sebesar 168.480.000 ton dan di Pasirgombong (Bayah) sebesar 123.000.000 ton. Penyebaran zeolit di Jawa Barat terdapat di Nanggung, Kalipucang, Cikembar, Gegerbitung, Cikalong, Cipatujah, dan Karangnunggal. Zeolit paling tidak ditemukan di tiga lokasi di Sulawesi, selain di Tana Toraja juga terdapat di Majene dan Bone (Kusdarto, 2008). Potensi zeolit yang ada di daerah tersebut berhubungan dengan batuan-batuan vulkanik berumur Oligosen-Miosen (Kusdarto, 2008).

Lokasi pertama penelitian zeolit terletak di daerah Swakan yang berdekatan dengan lokasi endapan zeolit Pasirgombong (Bayah). Zeolit terdapat pada Satuan Tuf Citorek yang telah mengalami alterasi dan metamorfosa lemah akibat proses geologi pembentukkan Kubah Bayah (Kusdarto, 2008; Sudjatmiko dan Santosa, 1992) (Gambar 1). Mineral utama penyusun batuan tersebut terdiri dari mika, plagioklas, dan kuarsa, dengan jenis zeolit yang dijumpai berupa mordenit dan klinoptilotit. Lokasi kedua terletak di daerah Cikembar dimana terdapat pada satuan tuf hijau, anggota tuf dan breksi dari Formasi Jampang yang berumur Miosen berupa tuf berwarna hijau berbatuapung, tuf hijau pasiran dan tuf hijau masif. Mineral utama penyusun batuan adalah plagioklas, kuarsa, kaolinit, monmorilonit dan kristobalit, dengan jenis zeolit yang dijumpai berupa klinoptilolit dan mordenit (Kusdarto, 2008).

Secara fisiografis Swakan terletak pada Zona Pegunungan Bayah dan Cikembar pada Zona Bogor. Zona ini disusun oleh batuan yang terlipat pada awal Tersier berarah utara-selatan. Endapan batuan Neogen tersebut terbagi atas batuan sedimen, batuan vulkanik, batuan terobosan dan batuan metamorf.

Secara stratigrafis batuan mengandung zeolit di daerah Bayah termasuk ke dalam Formasi Citorek berumur Pliosen Akhir. Formasi ini disusun oleh tuf batuapung, tuf kaca, breksi, dan lava (Sudjatmiko dan Santosa, 1992) (Gambar 1).
Daerah Cikembar terletak pada antiklinorium yang terpatahkan dengan kuat. Endapannya terdiri dari akumulasi endapan Neogen berupa endapan laut yang tebal, umumnya berupa endapan batulempung, batupasir, dan breksi. Zeolit di daerah ini berasosiasi dengan tuf hijau berbatuapung, tuf hijau pasiran, dan tuf hijau masif, yang keseluruhannya termasuk dalam satuan batuan tuf hijau, Anggota tuf dan Breksi dari Formasi Jampang berumur Miosen. Jenis mineral zeolit yang dijumpai adalah klinoptilolit dan mordenit dengan mineral lainnya yaitu plagioklas, kuarsa, kaolinit, monmorilonit, dan kristobalit (Rodiana, 2006).

\section{Genesa Zeolit}

Zeolit diemukan pada tuf yang mengalami sedimentasi dan mengalami alterasi (Kusdarto, 2008). Selain itu, zeolit ditemukan pada batuan sedimen atau batuan lainnya pada kondisi fisikakimia tertentu. Zeolit dapat terbentuk sebagai mineral hasil ubahan pada suatu sistem panasbumi, membentuk zona secara vertikal ataupun horizontal berdasarkan gradien komposisi alterasi dan suhu (Iijima, 1980). Terdapat beberapa model genesa pengendapan zeolit. Pada banyak kasus pengendapan zeolit dipengaruhi oleh beberapa model yang sulit untuk diidentifikasi di lapangan. Proses pembebanan, sirkulasi airtanah, hidrotermal atau metamorfisme kontak sulit diidentifikasi di lapangan kecuali dilakukan pemetaan secara lebih detil (Iijima, 1980).

Zeolit alam terbentuk sebagai mineral alterasi dari gelas vulkanik (Kusdarto, 2008), mineral lempung amorf, dan gel aluminosilikat (Ghiara et al., 1999). Zeolit menggantikan material kristalin seperti feldspar dan smektit, dan dapat terbentuk sebagai urat/vein atau mengisi rongga-rongga pada batuan dari larutan panas atau relatif dingin. Fragmenfragmen gelas vulkanik berbutir halus adalah material penting dalam pembentukkan zeolit untuk hampir seluruh tipe pembentukkan karena reaktifitasnya yang tinggi serta komposisi kimia yang sama dengan zeolit (Iijima, 1980). Tuf yang kaya zeolit tersusun oleh beberapa spesies berasal dari tuf gelas (vitric), dimana kandungan zeolit pada batuan ini dapat lebih besar dari $90 \%$ dari total masa batuan. Secara mikroskopis sangat sulit untuk mengidentifikasi gelas vulkanik teralterasi, fragmen gelas vulkanik dan mineral lempung (Iijima, 1980). Zeolit tipe mordenit 

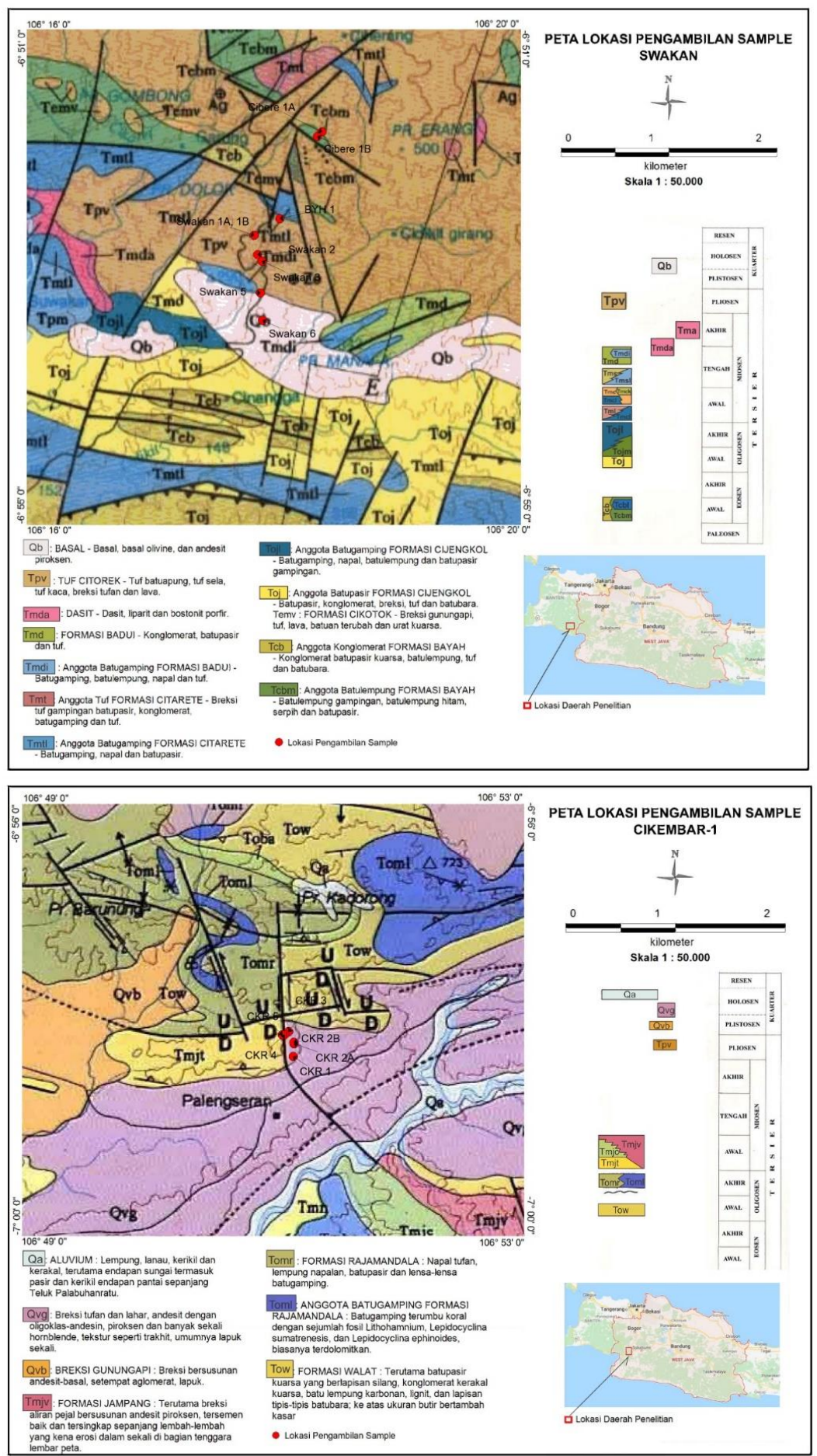

Gambar 1. Peta Geologi yang menunjukkan lokasi pengambilan sampel di daerah: a). Swakan, Bayah, wilayah Banten dan b). Cikembar, Sukabumi, Wilayah Jawa Barat. Beturut-turut modifikasi dari Peta Geologi Lembar Leuwidamar skala 1:100.000 (Sudjatmiko dan Santosa, 1992) dan Peta Geologi Lembar Bogor skala 1:100.000 (Effendi, 1974).

$\left(\mathrm{Na}_{2}, \mathrm{~K}_{2}, \mathrm{Ca}\right)\left[\mathrm{Al}_{2} \mathrm{Si}_{10} \mathrm{O}_{24}\right] \cdot \mathrm{H}_{2} \mathrm{O}$ dan klinoptilolit $\mathrm{Na}_{6}\left(\mathrm{Al}_{6} \mathrm{Si}_{30} \mathrm{O}_{72}\right) \cdot 24 \mathrm{H}_{2} \mathrm{O}$ adalah hasil ubahan dari gelas vulkanik (Ghiara et al., 1999).

\section{METODE}

Survei geologi pada lokasi-lokasi keterdapatan zeolit di daerah Swakan, Bayah dan Cikembar, 
Sukabumi diikuti dengan pengambilan dan pengumpulan sampel yang disertai koordinat GPS, deskripsi, dan foto dokumentasi. Sampel diambil pada lokasi-lokasi yang mewakili daerah sebaran zeolit dan batuan sampingnya. Untuk dapat mengetahui genesa zeolit dan hubungannya dengan keterdapatan unsur tanah jarang, maka sampel terpilih dianalisis untuk mendapatkan komposisi mineralogi dan kimia batuan. Adapun analisis yang dilakukan terdiri dari analisis petrografi, $X R D$, SEM, dan ICP-MS.

Analisis petrografi dilakukan untuk mengetahui komposisi mineralogi penyusun batuan baik mineral primer maupun sekunder. $X R D$ dilakukan untuk mengidentifikasi mineral terutama jenis zeolit dan mineral lempung. SEM dilakukan untuk mendapatkan bukti kehadiran mineral zeolit baik komposisi dan teksturnya secara detil. Sedangkan $I C P-M S$ dilakukan untuk mendapatkan komposisi unsur jejak termasuk unsur tanah jarang (UTJ). Analisis petrografi dan $X R D$ dilakukan di Laboratorium Fisika Mineral, Puslit Geoteknologi LIPI, Bandung. SEM dilakukan di Laboratorium Geologi Kuarter, Badan Geologi. Sedangkan analisis kimia dilakukan di laboratorium komersil Actlabs Ltd., Kanada.

\section{HASIL}

\section{Pengamatan Singkapan}

Penyelidikan geologi endapan zeolit yang dilakukan pada beberapa lokasi yang telah dilaporkan terdapat penambangan zeolit di Pasirgombong dan Cikembar Propinsi Banten dan Jawa Barat (Kusdarto, 2008) menunjukkan adanya gejala alterasi hidrotermal yang berasosiasi dengan endapan zeolit, yaitu di daerah Swakan (Bayah) dan Cikembar (Sukabumi). Peta lokasi pengamatan dan pengumpulan sampel dapat dilihat pada Gambar 1. Lokasi Swakan berdekatan dengan lokasi Pasirgombong. Batuan vulkanik teralterasi hidrotermal yang terbentuk di daerah Swakan dan sekitarnya tidak menunjukkan kumpulan mineral alterasi yang sama. Kumpulan mineral alterasi yang terbentuk di bagian utara Swakan terdiri dari klorit, mineral lempung, mineral-mineral bijih sulfida, sebagian teroksidasi kuat, dan mengandung terobosan urat kalsit dan kuarsa (Gambar 2a-b). Umumnya singkapan adalah tuf lapili teralterasi, bertekstur klastik, berwarna hijau, terdiri dari fragmen batuan vulkanik dan kristal serta kumpulan mineral alterasi klorit, kuarsa dan mineral lempung. Singkapan yang relatif sama dijumpai di daerah Swakan namun berasosiasi dengan kehadiran zeolit, serta tidak terdapat urat kuarsa dan kalsit.

Pada lokasi Swakan (1A dan 1B), tuf teralterasi berasosiasi dengan zeolit, namun memiliki intensitas alterasi yang lebih lemah dibandingkan dengan lokasi pada bagian utaranya. Fenomena ini dapat mengindikasikan perbedaan karakter batuan, komposisi dan proses hidrotermal yang mempengaruhi kedua lokasi tersebut.

Tuf teralterasi menunjukkan tekstur klastik, berwarna putih kehijauan sampai keabu-abuan, berbintik-bintik berwarna putih dan kuning kecoklatan, berbutir halus sampai agak kasar, kompak, dan terkekarkan. Tuf teralterasi ini terutama disusun oleh silika, zeolit, dan oksida besi (Gambar 2e). Pada singkapan Swakan 3, tuf teralterasi berwarna abu-abu kehijauan, bertekstur klastik, memiliki bintik-bintik putih yang diduga ubahan mineral lempung, berbutir halus sampai agak kasar, kompak dan memiliki retakan pada beberapa tempat. Fragmen kristal penyusun batuan diduga telah teralterasi menjadi silika dan zeolit. Oksida besi hadir mengisi rekahan-rekahan batuan bersama-sama dengan mineral lempung (Gambar 2f). Pada lokasi lainnya, mineral alterasi didominasi oleh mineral lempung dan silika (Swakan 5). Lava berkomposisi andesit-basaltik, berwarna hitam, masif, terdapat di atas batuan teralterasi, bertekstur kristalin dengan ukuran kristal halus, dan telah teralterasi yang dicirikan oleh kehadiran mineral klorit dan silika. (Gambar 2g-h)

Pada lokasi Cikembar (Sukabumi), zeolit ditemukan berhubungan dengan batupasir tufan. Hal ini berbeda dengan zeolit di Swakan yang berasosiasi dengan tuf teralterasi (Gambar 3). Batupasir tufan berwarna abu-abu kehijauan sampai hijau pucat, klastik, memiliki perlapisan, disusun oleh aneka fragmen batuan, umumnya material batuan piroklastik, berbutir sedang-agak kasar, menyudut-membundar tanggung, terpilah buruk dengan kemas terbuka, terdiri dari aneka fragmen batuan seperti fragmen batuan vulkanik, 
batuan sedimen berwarna hitam, fragmen batuan terubah, zeolit, dan mineral lempung sebagai matriks (Gambar 3c). Zeolit berwarna hijau transparan sampai transparan, tersebar tidak merata umumnya menunjukkan penjajaran dengan bidang perlapisan, diduga menggantikan fragmen gelas vulkanik dan batuapung (pumice), berbutir
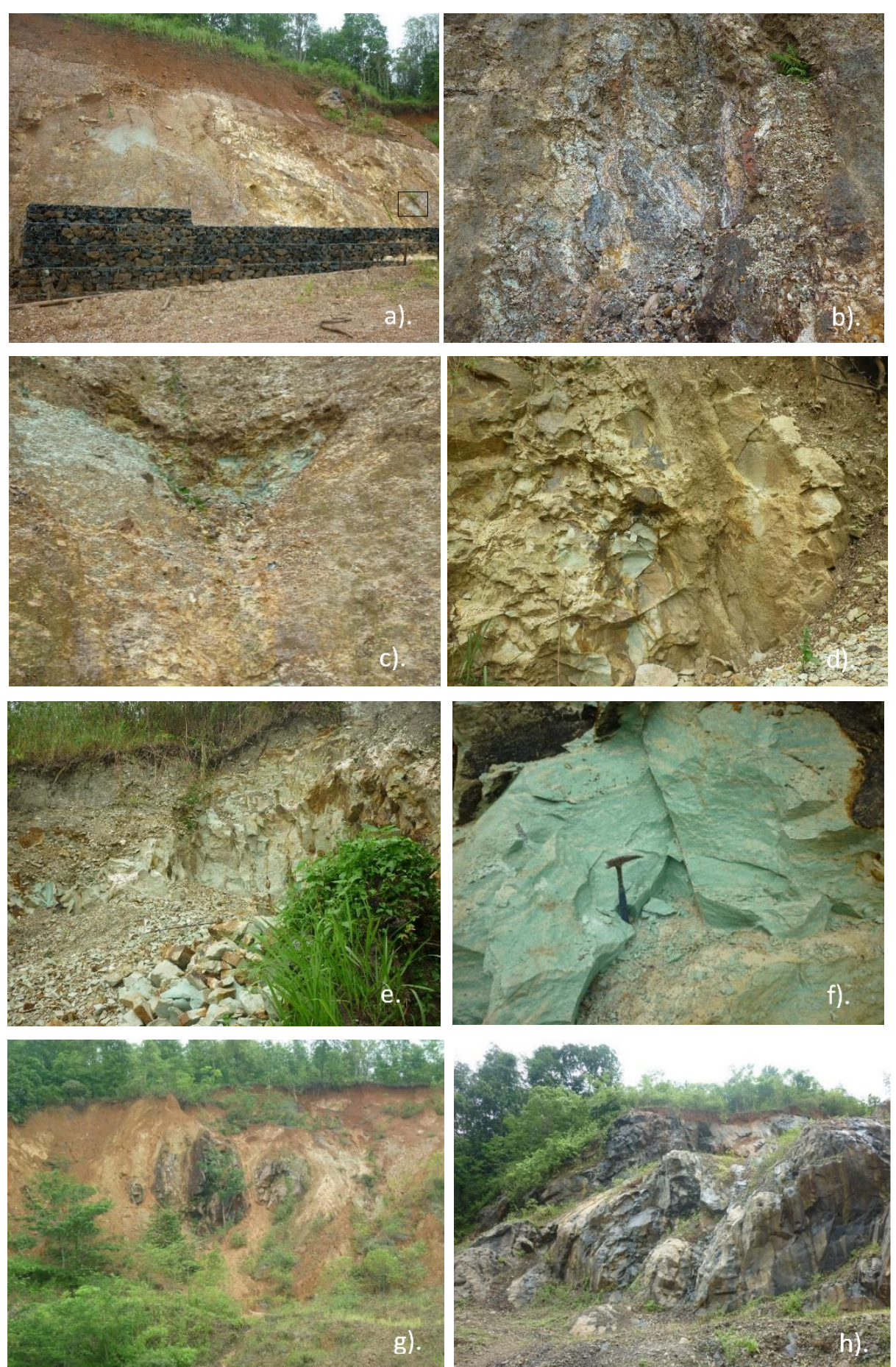

Gambar 2. a). Singkapan tuf terubah akibat proses hidrotermal daerah Cibere sebelah utara Swakan, Bayah menunjukkan produk hasil alterasi berupa mineral lempung, silika, mineral bijih sulfida dan b). pengkayaan oksida besi, c-e). Di daerah Swakan, proses hidrotermal lebih dicirikan oleh tuf yang berasosiasi dengan kumpulan mineral alterasi silika, mineral lempung dan f). zeolit. Sementara g-h). Batuan vulkanik yang mengalami silisifikasi. 

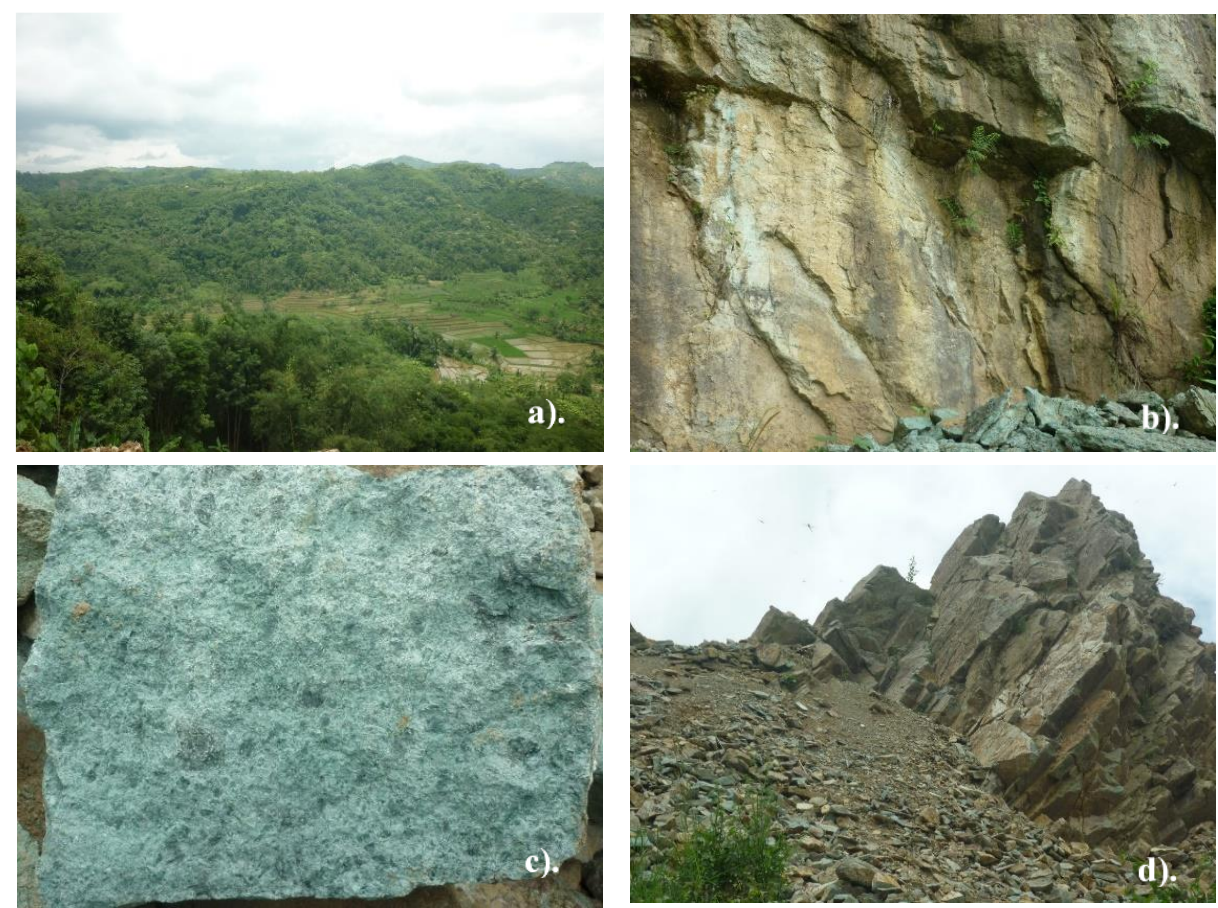

Gambar 3. a). Morfologi perbukitan volkanik bergelombang terlipat tersesarkan daerah Cikembar dan sekitarnya (foto diambil dari arah barat), b). Singkapan tuf terubah dengan penampakan bidang perlapisan dan bidang sesar. c). Zeolit transparan agak kehijau-hijauan, tersebar tidak merata menggantikan gelas volkanik, d). batupasir tufan tersesarkan, intensitas alterasinya semakin berkurang, mineral feldspar dapat diamati dengan jelas, selain itu terdapat oksida besi dan mangan.

halus sampai agak kasar, dan agak keras sampai tidak dapat diremas (Gambar 3c).

Batupasir tufan mengandung mineral zeolit di Cikembar ditunjukkan oleh sampel dengan kode CKR 3, 4, dan 5. Batuan menunjukkan tekstur yang berbeda dengan singkapan di daerah Swakan. Di daerah Cikembar terdapat mineral alterasi silika serta mineral zeolit yang tersebar mengikuti perlapisan batuan, yaitu antara fragmen butiran halus dengan fragmen butiran kasar. Fenomena lainnya yang ditemukan di lokasi pengamatan adalah terdapatnya bidang sesar vertikal yang mengandung cermin sesar (Gambar $3 b, d)$.
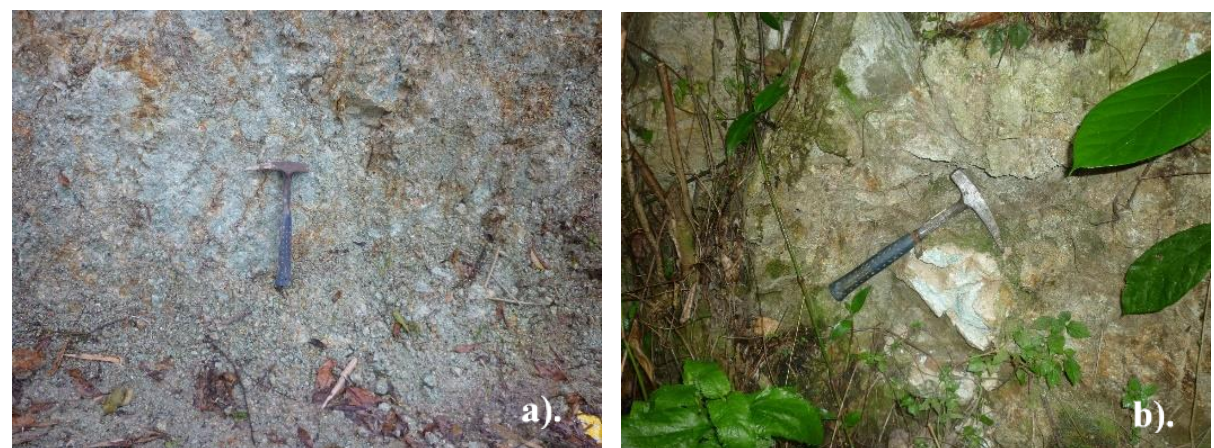

Gambar 4. a). Singkapan batupasir tuf terubah lemah berwarna abu-abu kehijauan, terpilah buruk dan kemas terbuka. Batuan tersusun oleh fragmen batuan volkanik, feldspar, mineral lempung (kaolinit), zeolit, dan klorit. Zeolit memiliki butiran sedang sampai kasar dan tersebar tidak merata. Oksida besi terbentuk pada bagian rekahan batuan. b). Ubahan silika tampak berasosiasi dengan mineral zeolit, berwarna putih kehijau-hijauan. Zeolit tersebar pada matriks batuan menunjukkan perlapisan, berbutir halus sampai agak kasar. 
Batupasir tufan mengandung zeolit di Cikembar pada saat ini ditambang oleh masyarakat sebagai bahan ornamen bangunan, tidak lagi sebagai pakan hewan atau obat-obatan. Hal ini karena secara kualitas komposisi zeolit semakin berkurang. Semakin dominannya kehadiran mineral pengotor seperti kuarsa, feldspar, fragmen, dan mineral lempung yang hadir bersama dengan jumlah yang lebih banyak, mengakibatkan kualitas zeolit semakin berkurang. Batupasir tufan berwarna abu kehijau-hijauan mengalami alterasi yang dicirikan oleh kehadiran klorit dan mineral lempung. Pada lokasi ini, tekstur dan struktur yang ditunjukkan relatif sama dengan singkapan sebelumnya, namun secara megaskopik terlihat mineral feldspar berbentuk euhedral dan segar (fresh). Sedangkan zeolit tersebar bersama matriks menggantikan gelas vulkanik dan fragmen gelas vulkanik, berbutir halus serta membentuk kesan perlapisan dengan fragmen batuan yang lebih kasar. Batuan mengalami oksidasi dicirikan oleh kehadiran mineral oksida besi dan mangan. Sebagai pembanding, di daerah Gegerbitung (GGB 1), singkapan batupasir tufan memiliki penyebaran yang terbatas. Singkapan batupasir tufan menunjukkan warna abu-abu kehijauan sampai putih kekuning-kuningan menggambarkan komposisi jenis alterasi mineral lempung yang berbeda. Batuan tersusun oleh terutama kelompok mineral lempung dan oksida besi. Breksi vulkanik teralterasi dijumpai diterobos oleh urat-urat kuarsa berasosiasi dengan kehadiran mineral bijih sulfida (Gambar 4a-b). Sampel batupasir tufan dari Gegerbitung ini tidak dibahas lebih lanjut, karena singkapan sudah mengalami pelapukan cukup intensif.

Deskripsi singkapan batuan mengandung zeolit di daerah Swakan dan Cikembar menunjukkan karakteristik megaskopik batuan yang berbeda. Batuan mengandung zeolit daerah Swakan (Bayah) adalah tuf, tersebar cukup luas, berwarna putih kehijauan sampai hijau gelap, berasosiasi dengan kehadiran kumpulan mineral alterasi terdiri dari klorit, kuarsa, kalsit, epidot, dan mineral opak. Endapan zeolit di daerah ini terdapat pada tuf yang dapat disetarakan dengan Satuan Tuf Citorek yang telah mengalami ubahan (Sudjatmiko dan Santosa, 1992). Menurut Kusdarto (2008) yang melakukan penelitian zeolit daerah Pasirgombong, berdekatan dengan lokasi penelitian, melaporkan bahwa hasil $X R D$ menunjukkan zeolit bertipe mordenit $(32,70 \%)$, dan klinoptilotit (30,89\%). Mineral-mineral pengotor yang hadir terdiri dari mika, plagioklas, dan kuarsa. Pada lokasi lain yaitu di daerah Cikembar, zeolit terdapat pada batupasir tufan. Keterdapatan zeolit pada batuan menunjukkan penyebaran yang terbatas, tidak seluas seperti yang terdapat di daerah Swakan. Di Cikembar zeolit terdapat sejajar mengikuti perlapisan batupasir tufan, sehingga dapat diduga pembentukan zeolit berhubungan dengan proses pembebanan atau diagenesa. Batupasir tufan ini termasuk dalam satuan batuan tuf hijau, Anggota tuf dan breksi dari Formasi Jampang yang berumur Miosen.

\section{Petrografi}

Petrografi dilakukan pada sampel batuan terpilih yang mengandung mineral zeolit. Tiga buah sampel terpilih diambil dari Cikembar (CKR) dan Swakan (Swakan). Secara mikroskopis batupasir tufan dari Cikembar (CKR 2B) tidak berwarna sampai abu-abu kecoklatan, terpilah buruk dengan kemas terbuka, terdiri dari fragmen batuan dan kristal yang tertanam di dalam aliran gelas vulkanik (5a-b). Tuf disusun oleh fragmen kristal kuarsa, mineral opak (3\%), dan fragmen batuan (2\%), berbentuk menyudut sampai menyudut tanggung tertanam di dalam matriks gelas vulkanik (85\%) dan mineral lempung (10\%). Mineral zeolit terbentuk sebagai hasil ubahan gelas vulkanik $(55 \%)$, bertekstur granular dan spherulitik (Gambar 5). Tuf Swakan (Swakan) tidak berwarna sampai abu-abu kecoklatan, terpilah buruk dengan kemas terbuka, disusun oleh fragmen batuan (2\%), mineral opak (1\%), kuarsa $(1 \%)$, dan feldspar. Seluruh fragmen tertanam di dalam matriks gelas vulkanik (62\%) dan mineral lempung (35\%). Zeolit (20\%) terutama hasil ubahan dari gelas vulkanik dan beberapa ditemukan menggantikan feldspar. Mineral feldspar yang digantikan zeolit menunjukkan tekstur relik (Gambar 6). 

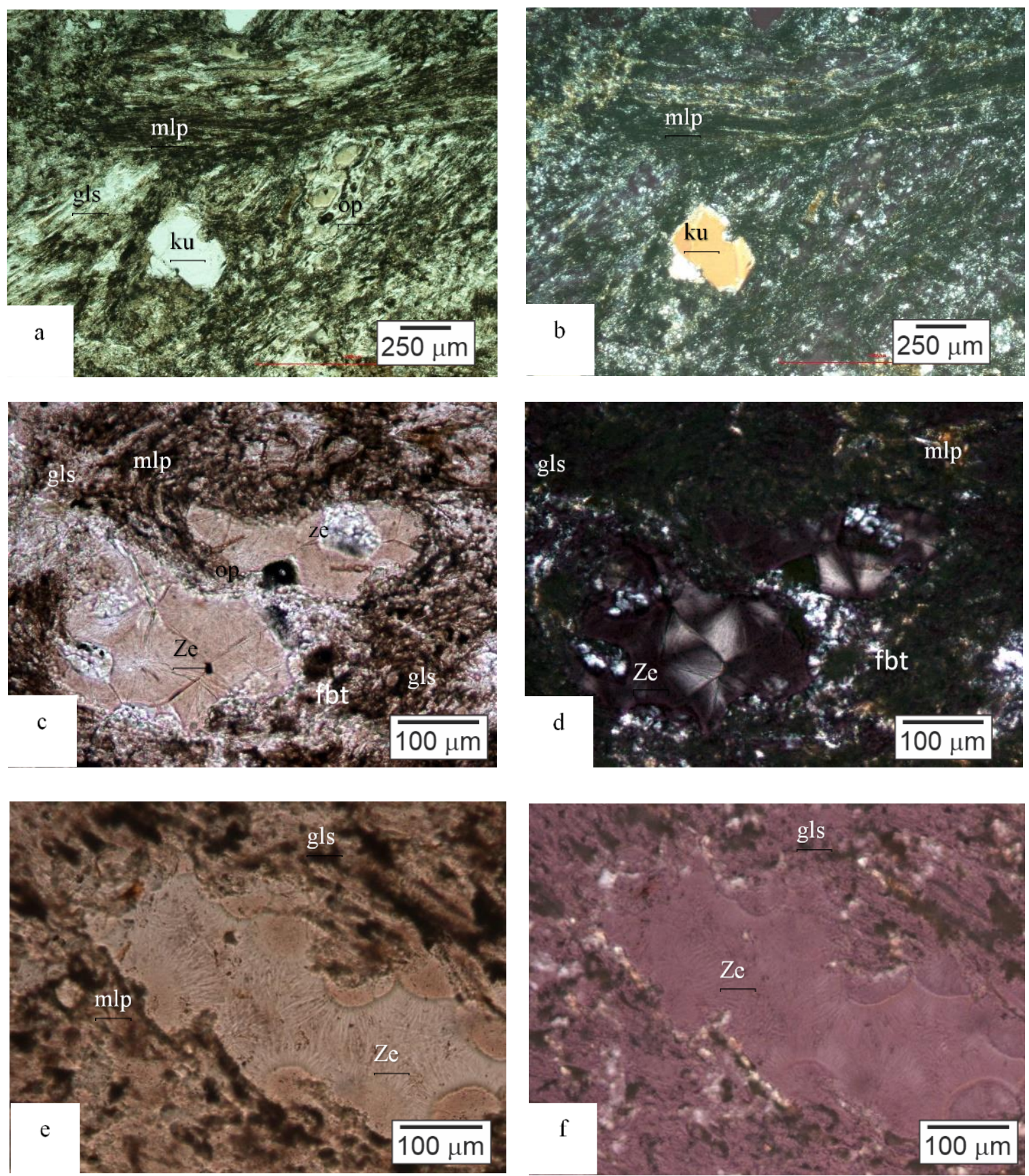

Posisi nikol sejajar

Posisi nikol bersilang

Gambar 5. Batupasir tufan mengandung zeolit. Zeolit terbentuk sebagai hasil ubahan gelas. Keterangan: gls=gelas volkanik, op=mineral opak, $\mathrm{ku}=$ kuarsa, $\mathrm{ze}=$ zeolit.

\section{X-Ray Diffraction (XRD)}

Tuf mengandung zeolit dari Swakan 1 menunjukkan kehadiran beberapa grup puncak yang diidentifikasi sebagai mineral mordenit (klinoptilolit/heulandit ?) dan feldspar (Gambar 6). Mordenit memiliki puncak pada 2 theta $\left(^{\circ}\right)$ berturut-turut 10,$02 ; 13,50 ; 19,72 ; 22,46 ; 25,74$; dan 27,74 sedangkan dari Cikembar pada 22,48; 25,76; dan 27,72 (Gambar 7).

\section{Unsur Utama}

Analisis kuantitatif batuan (whole rock) dilakukan untuk mengetahui komposisi unsur utama (major elements) dilakukan dengan $X R F$ di laboratorium Actlabs, Kanada (Tabel 1). Komposisi utama dari 

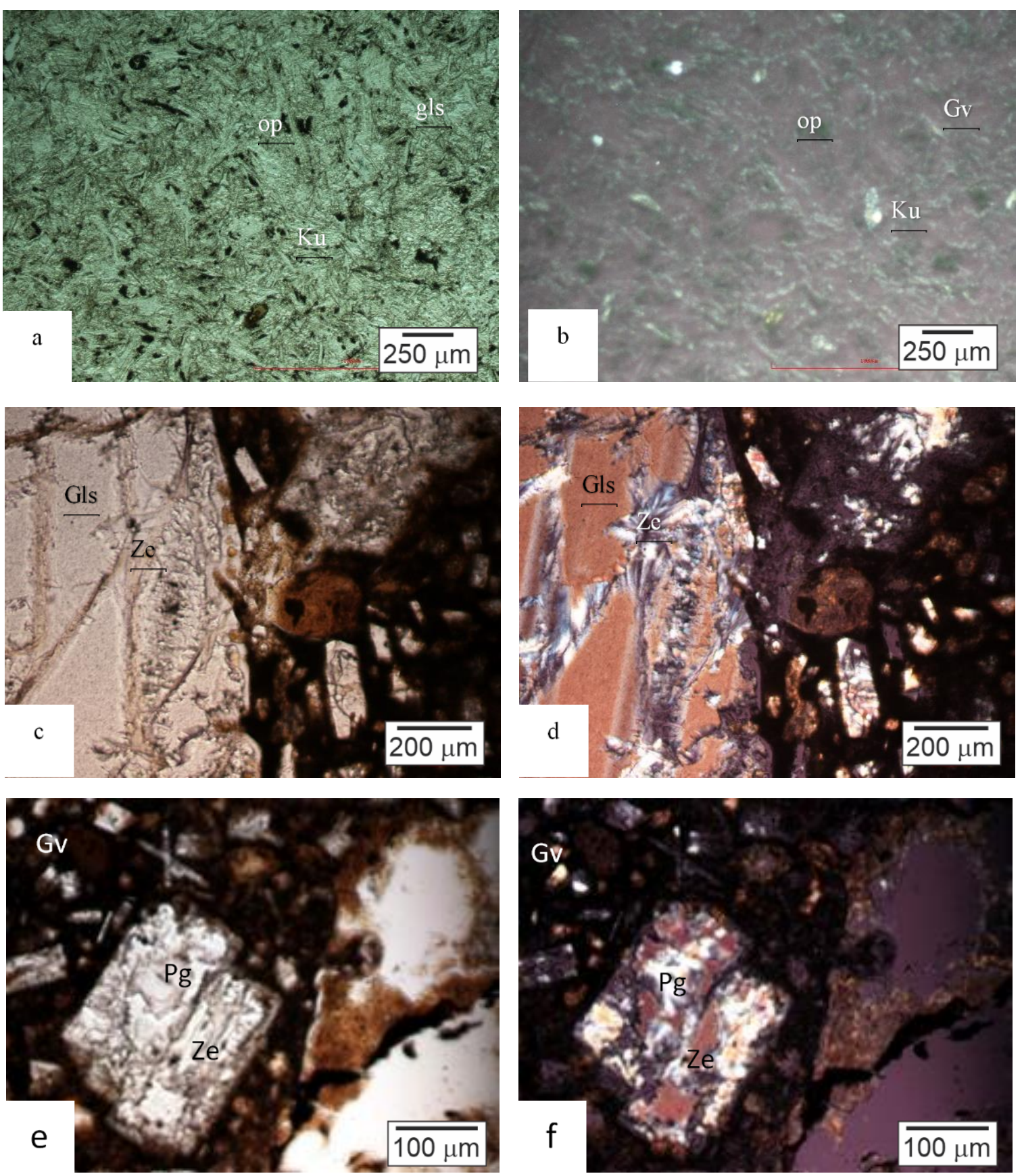

Posisi nikol sejajar

Posisi nikol bersilang

Gambar 6. Tuf gelas yang disusun oleh relik-relik feldspar digantikan oleh zeolit dan zeolit menggantikan matriks. Keterangan: gls= gelas volkanik, op=mineral opak, ku=kuarsa, ze=zeolit.

zeolit didominasi oleh silika dan almunium yang membentuk kerangka utama dari kristal zeolit. Berdasarkan hasil analisis (Tabel 1), kandungan sodium besar terutama dari daerah Swakan dan Cikembar, berturut-turut berkisar antara 0,34 $3,86 \%$ dan $0,73-1,65 \%$, berasal dari feldspar (plagioklas termasuk jenis albit) dan juga mineral zeolit itu sendiri (mis. mordenit/heulandit?).
Selain itu potasium berkisar antara $0,95-2,52 \%$ untuk daerah Swakan, dan 1,13-3,94\%, juga merupakan unsur dengan jumlah besar yang berasal dari zeolit tipe mordenit, kalsium dan magnesium sebagai mineral pengotor juga terdapat pada kristal 

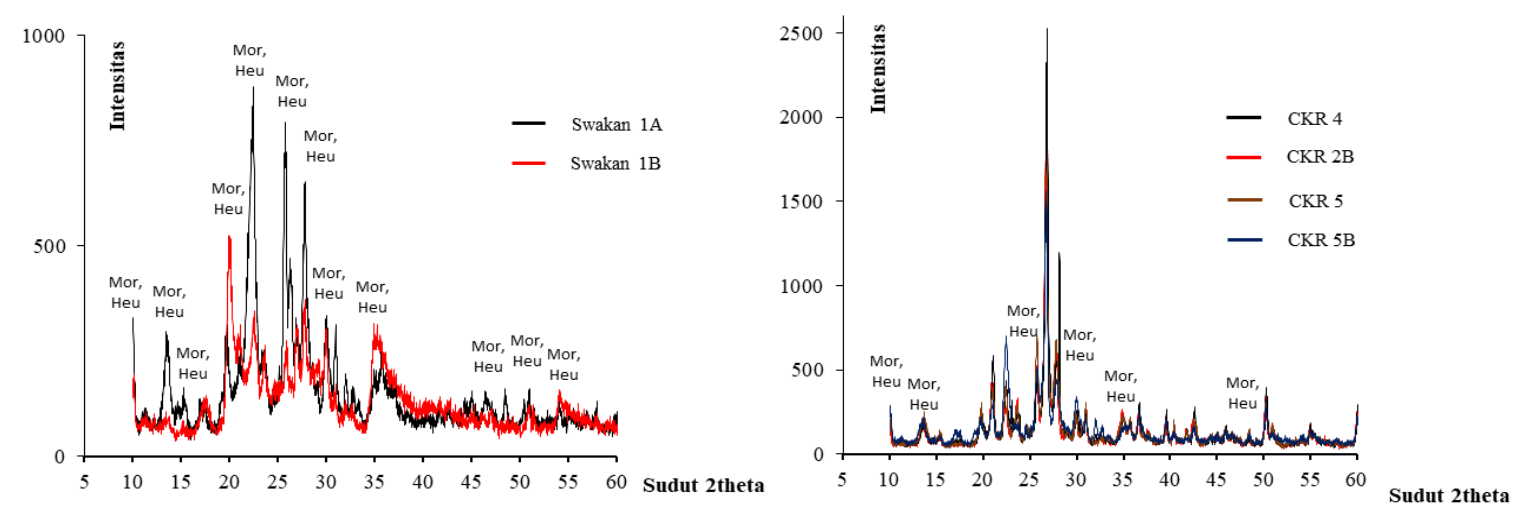

Gambar 7. Difraktogram XRD sampel dari Swakan (Swakan 1A) dan Cikembar (CKR 5B). Keterangan: Mor=mordenit, $\mathrm{Heu}=$ heulandite; $\mathrm{Ku}=$ kuarsa; $\mathrm{Al}=\mathrm{albit}$.

zeolit sebagai penetralisir muatan yang bergerak bebas dan dapat dipertukarkan. Pengotor lainnya adalah besi. $\mathrm{SiO}_{2}$ daerah Swakan berkisar antara 56-69\%, sedangkan dari Cikembar berkisar antara $68-69 \%$.

\section{Unsur Jejak dan Unsur Tanah Jarang}

Analisis batuan (whole rock) pada batupasir tufan daerah Cikembar menunjukkan kandungan Ba dan Sr antara 276-677 ppm dan 205-692 ppm. Sedangkan pada tuf daerah Swakan kandungan Ba dan Sr antara 140-319 ppm dan 69-369 ppm. Kandungan $\mathrm{Zr}$ pada tuf Swakan dan batupasir tufan Cikembar berturut turut 88-116 ppm dan 73-136 ppm.

Kandungan UTJ pada batupasir tufan mengandung zeolit Cikembar (total 4 sampel) antara 82-94 ppm, dengan rata-rata $87 \mathrm{ppm}$. Sedangkan tuf di daerah Swakan (total 3 sampel) total UTJ antara 71-83 ppm dengan rata-rata 78 ppm. Kandungan UTJ di Swakan berasosiasi dengan keterdapatan batuan teralterasi. Kandungan UTJ relatif lebih besar di Cikembar walaupun memiliki penyebaran alterasi lebih sempit dibandingkan dengan di Swakan. Batupasir tufan dari Cikembar memiliki kandungan $\mathrm{SiO}_{2}$ antara 68-69\% relatif lebih besar dibandingkan dengan tuf Swakan yang memiliki kandungan $\mathrm{SiO}_{2}$ antara 56-69\%. Namun meskipun komposisi $\mathrm{SiO}_{2}$ nya berbeda, kandungan UTJ pada dua jenis batuan di dua lokasi tersebut tidak berbeda cukup signifikan.

\section{Scanning Electron Microscope (SEM)}

Mineral zeolit yang teridentifikasi menggunakan SEM pada sampel Swakan adalah mordenit dan klinoptilolit. Mordenit berbentuk sebagai masa yang membulat dan berserabut (rounded fiber-like masses). Hasil analisis SEM menunjukkan proporsi mordenit dan klinoptilolit hampir sama. Klinoptilolit hadir sedikit lebih banyak daripada mordenit. Mordenit ditemukan sebagai kristal

Tabel 1. Unsur utama batuan mengandung zeolit daerah Cikembar dan Swakan.

\begin{tabular}{lccccccccccr}
\hline $\begin{array}{c}\text { Kode } \\
\text { Sampel }\end{array}$ & $\mathbf{S i O}_{2}$ & $\mathbf{A l}_{2} \mathrm{O}_{3}$ & $\mathbf{F e}_{2} \mathrm{O}_{3}$ & $\mathbf{M n O}$ & $\mathbf{M g O}$ & $\mathbf{C a O}$ & $\mathbf{N a}_{2} \mathbf{O}$ & $\mathbf{K}_{2} \mathbf{O}$ & $\mathbf{T i O}_{2}$ & $\mathbf{P}_{2} \mathrm{O}_{5}$ & LOI \\
\hline Swakan 1A & 69,09 & 11,06 & 1,11 & 0,011 & 0,52 & 2,29 & 0,72 & 2,52 & 0,151 & 0.01 & 12,6 \\
Swakan 1B & 55,75 & 18,16 & 2,64 & 0,137 & 1,88 & 1,79 & 0,34 & 1,64 & 0,216 & 0.01 & 17,59 \\
Swakan 6 & 57,63 & 18,2 & 5,87 & 0,142 & 1,98 & 6,59 & 3,86 & 0,95 & 0,614 & 0,13 & 4,34 \\
\hline CKR 2B & 68,37 & 12,47 & 1,8 & 0,045 & 0,73 & 1,75 & 1,03 & 3,94 & 0,143 & 0.01 & 9,78 \\
CKR 4 & 69,53 & 11,84 & 1,33 & 0,022 & 0,62 & 1,77 & 0,73 & 3,37 & 0,123 & 0.01 & 9,83 \\
CKR 5 & 68,82 & 12,09 & 1,48 & 0,054 & 0,63 & 2,09 & 1,65 & 3,32 & 0,105 & 0.01 & 9,94 \\
CKR 5B & 68,22 & 11,38 & 1,63 & 0,03 & 0,84 & 2,96 & 1,09 & 1,13 & 0,172 & 0.01 & 13,03 \\
\hline
\end{tabular}

Keterangan: Kode sampel Swakan berasal dari Swakan, CKR berasal dari Cikembar 


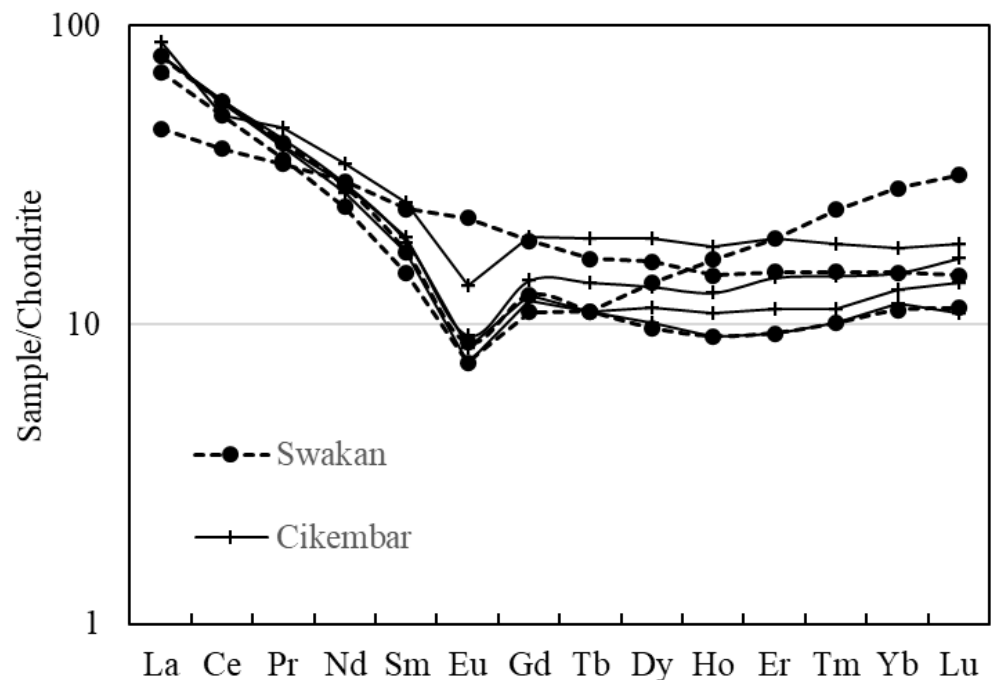

Gambar 8. Diagram laba-laba unsur tanah jarang batuan mengandung zeolit menunjukkan karakter genetik batuan volkanik berasal dari zona subduksi.

jarum dan fibrous sedangkan klinoptilolit ditemukan sebagai kristal berbentuk kubus (Gambar 9). Klinoptilolit memiliki kesamaan struktur dan terbentuk akibat solid solution (Gottardi and Galli, 1985; Iijima, 1980)

\section{PEMBAHASAN}

Pada bagian ini akan didiskusikan geologi endapan zeolit serta hubungan antara zeolit dengan UTJ di daerah penelitian.

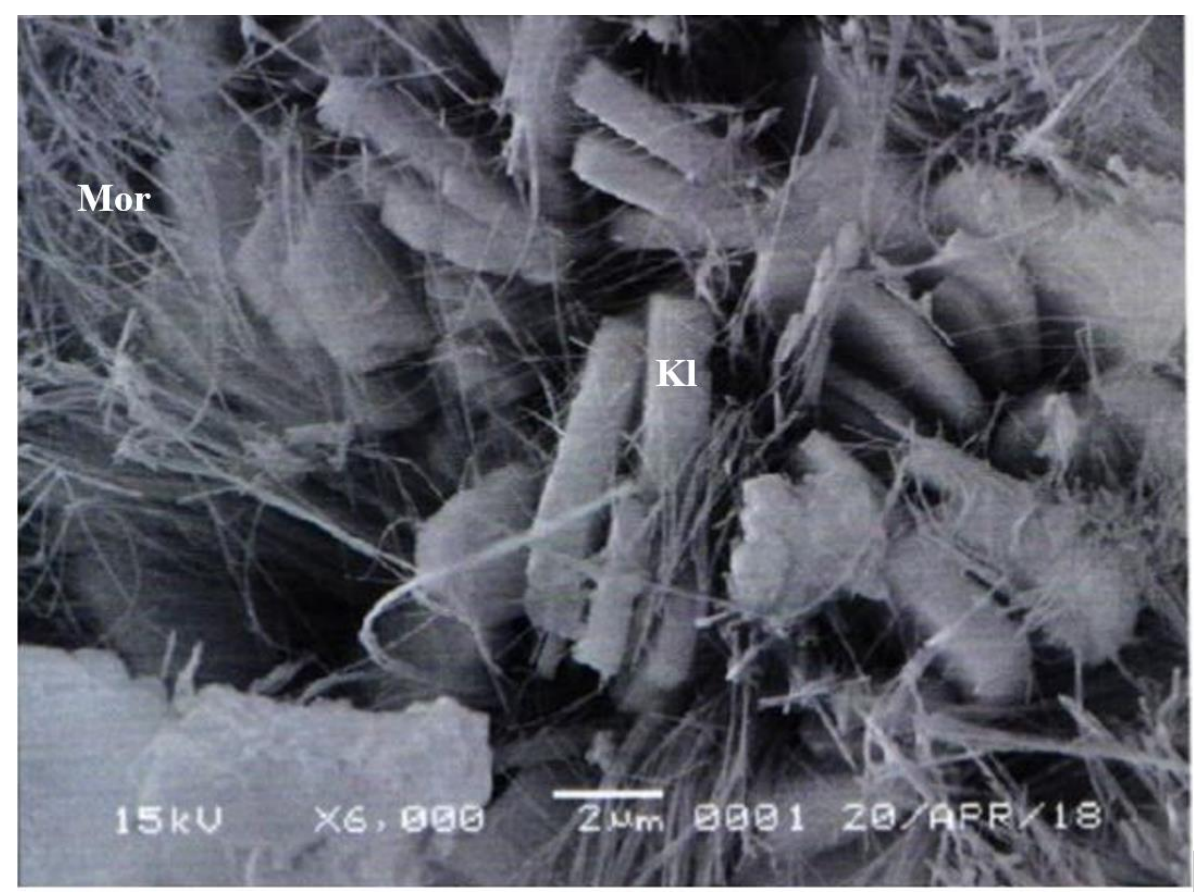

Gambar 9. SEM dari zeolit yang terbentuk pada tuf gelas mengandung zeolit daerah Swakan menunjukkan mordenit, membentuk serabut halus, dan klipnotilolit memiliki bentuk seperti kubus memanjang. Keterangan: Mor=mordenit; Kl=klinoptilolit. 


\section{Geologi Endapan Zeolit}

\section{Penyebaran Zeolit dan Jenis Batuan Induk}

Secara stratigrafi keterdapatan zeolit di daerah Swakan (Bayah) terdapat pada Formasi Citorek (Sudjatmiko dan Santosa, 1992). Sedangkan zeolit yang terdapat di daerah Cikembar terdapat pada Formasi Batuan Vulkanik Kuarter produk Gunung Gede $(\mathrm{Qvg})$ yang mengalami diagenesis. Hal ini berbeda dengan pendapat peneliti sebelumnya yang menyatakan zeolit Cikembar terdapat pada satuan tuf hijau Formasi Jampang seperti yang disebutkan Kusdarto (2008). Selain berdasarkan pengamatan lapangan, plot lokasi pada peta geologi pun menunjukkan lokasi sampel daerah Cikembar yang tidak terdapat pada Formasi Jampang, meskipun lokasi sampel dekat dengan zona komplek struktur yang memungkinkan terjadinya percampuran atau pemindahan atau pengendapan ulang batuan akibat struktur (rombakan) (Gambar 1).

Mineral zeolit terdapat di daerah Swakan berasosiasi dengan tuf lapilli dan lava berkomposisi andesit-basaltik yang telah teralterasi akibat proses hidrotermal. Sedangkan zeolit daerah Cikembar berasosiasi dengan batupasir tufan. Pembentukkan zeolit kemungkinan akibat proses diagenesis. Model diagenesis untuk daerah Cikembar berkesesuaian dengan model diagenesis dalam sistem hidrologi terbuka (Gottardi, 1989). Sistem ini terbentuk ketika air meteorik yang menjalar masuk ke bawah lapisan batupasir tufan berubah menjadi alkalin dan merubah $\mathrm{pH}$ menjadi lebih tinggi. Air tersebut kemudian bergerak semakin ke bawah, sementara di permukaan, gelas vulkanik terubah menjadi mineral lempung, sedikit lebih dalam menjadi zeolit (Gambar 5a-h). Fragmen batuan, fragmen kristal, dan mineral lempung secara megaskopik masih dapat diamati.

Distribusi batuan mengandung zeolit di Swakan berhubungan dengan sebaran batuan vulkanik yaitu tuf lapilli, sedangkan di Cikembar berasosiasi dengan batuan hasil rombakan batuan vulkanik, yaitu batupasir tufan. Menurut penelusuran Peta Geologi Lembar Bayah (Sudjatmiko dan Santosa, 1992), tuf daerah Swakan secara stratigrafi termasuk ke dalam Formasi Citorek berumur Pliosen (Tpv). Sedangkan batupasir tufan daerah Cikembar secara stratigrafi, lebih muda daripada Formasi Citorek, terdapat pada Formasi Batuan Vulkanik
Kuarter (Qvg) (Effendi, 1974). Daerah Cikembar dan Swakan disusun oleh batuan-batuan vulkanik yang berhubungan dengan volkanisme jaman Pliosen.

Komposisi $\mathrm{SiO}_{2}$ tuf daerah Swakan (57-69\%) memiliki kisaran yang lebih lebar dibandingkan dengan batupasir tufan daerah Cikembar (6869\%). Kedua jenis batuan menunjukkan nilai LoI yang tinggi. Secara umum batupasir tufan Cikembar memiliki komposisi yang lebih asam yaitu berkomposisi dasitik, sedangkan tuf Swakan memiliki komposisi andesitik-dasitik. Perbedaan komposisi $\mathrm{SiO}_{2}$ ini mengindikasikan pada kedua lokasi tersebut telah dipengaruhi aktifitas magmatik yang berbeda.

\section{Pembentukkan Zeolit dari Gelas Vulkanik}

Pembentukkan zeolit di daerah penelitian terutama berasal dari gelas vulkanik yang mengalami proses hidrasi (Gambar 5). Proses tersebut berupa reaksi kimia migrasi ion-ion $\mathrm{Ca}$, $\mathrm{Na}, \mathrm{K}, \mathrm{Mg}$, silika dan alumina dengan gelas vulkanik serta air pengisi pori batuan (Iijima, 1980). Proses lain yang terjadi adalah unsur alkali yang terlindi atau terlepas (leached) yang mengakibatkan naiknya $\mathrm{pH}$ dan alkalinitas air pori, sehingga mengakibatkan pelarutan gelas vulkanik. Silika dan alumina yang juga terlepas dari gelas vulkanik digunakan sebagai kerangka pembentukkan kristal zeolit (Iijima, 1980). Pembentukkan zeolit di Swakan berasosiasi dengan kumpulan mineral alterasi (lihat pembahasan petrografi). Kehadiran asosiasi mineral alterasi tersebut mengindikasikan bahwa pembentukkan zeolit berhubungan dengan mineral alterasi akibat proses hidrotermal. Proses yang terjadi kemungkinan seperti yang diuraikan IIjima (1980) yaitu akibat terlarutnya gelas vulkanik dan membentuk gel aluminosilika yang kemudian berubah menjadi zeolit dengan kondisi $\mathrm{pH}$ netral-alkali. Bukti lainnya adalah terdapat relik mineral yang diduga jejak mineral feldspar dapat diamati pada hasil analisis petrografi yang digantikan oleh zeolit (Gambar 5). Zeolit daerah Swakan memiliki derajat kemampuan tukar kation (KTK) sebesar $84.17 \mathrm{meq} / 100$ gr (Estiaty et al., 2018). Nilai tersebut merupakan jumlah kation yang mampu dipertukarkan dari zeolit alam sebelum mengalami aktivasi. Zeolit daerah Swakan ini dianggap cukup baik digunakan sebagai media preservasi bakteri (Estiaty et al., 2018). 
Tabel 2. Ringkasan mineralogi, tipe zeolit dan UTJ dari Swakan, dan Cikembar.

\begin{tabular}{lcccc}
\hline $\begin{array}{c}\text { Kode } \\
\text { sampel }\end{array}$ & $\sum$ UTJ & Fase mineral & $\begin{array}{c}\text { Kisaran } \sum \text { UTJ, } \\
\text { Rata-rata (ppm) }\end{array}$ & Tipe zeolit \\
\hline Swakan 1A & 82,59 & $K u, M o r, D i$ & & Mordenit \\
Swakan 1B & 80,42 & $K u, M o r$, Di, Ant & $(71-83), 78$ & Mordenit \\
Swakan 6 & 71,01 & $A l b$, Tri & & \\
\hline CKR 2B & 84,49 & $K u$, Mor & & Mordenit \\
CKR 4 & 93,53 & $K u$, Mor, San & $(82-94), 87$ & Mordenit \\
CKR 5 & 81,58 & $K u$, Mor & & Mordenit \\
CKR 5B & 86,44 & $K u, M o r$, Alb & & Mordenit \\
\hline
\end{tabular}

Keterangan: $\mathrm{Ku}=\mathrm{kuarsa}$, Mor=mordenit, $\mathrm{Di}=$ dikit, Ant=antigorite, $\mathrm{Alb}=\mathrm{albit}$, Tri=tridimit, San=sanidin

Hasil analisis XRD mengkonfirmasi kehadiran zeolit dengan tipe mordenit dan klinoptilolit (heulandit). Sulit untuk membedakan klinoptilolit dengan heulandit kedua tipe zeolit tersebut memiliki struktur yang hampir sama. Menurut Iijima (1980) mordenit dan heulandit terbentuk pada fase awal disolusi gelas vulkanik. Keterdapatan zeolit sangat sulit ditemukan pada sayatan tipis pengamatan petrografi.

\section{Hubungan antara Zeolit dan UTJ}

Konsentrasi UTJ pada tuf (whole rock) mengandung zeolit di Swakan antara 71-83 ppm, dengan rata-rata $78 \mathrm{ppm}$, sedangkan batupasir tufan Cikembar antara 82-94 ppm, dengan ratarata $87 \mathrm{ppm}$. Konsentrai UTJ ini lebih besar daripada tuf mengandung sedikit zeolit di daerah Cibeber 47 ppm (Estiaty et al., 2018) (Tabel 2). Kumpulan mineral alterasi di daerah Swakan dan Cikembar berbeda dengan di daerah Cibeber dan Gegerbitung, yaitu disusun oleh klorit, zeolit, mineral lempung, dan kuarsa. Sedangkan batupasir tufan di Cibeber dan Gegerbitung didominasi oleh kuarsa dan oksida besi (Estiaty et al., 2018).

Kandungan UTJ pada tuf dan batupasir tufan di daerah Swakan dan Cikembar tidak menunjukkan perbedaan yang signifikan, berturut-turut memiliki rata-rata sebesar 78 ppm dan 87 ppm. Proses hidrotermal yang terjadi di Swakan diduga tidak berhubungan dengan konsentrasi UTJ di daerah Swakan.

Perlu dilakukan analisis lanjutan untuk melihat kemungkinan UTJ berhubungan dengan pembentukkan mineral lempung seperti halnya model pengkayaan UTJ pada tanah lapukan (Sanematsu et al., 2013).

Kandungan UTJ pada tuf dan batupasir tufan di Swakan dan Cikembar ini lebih dipengaruhi oleh komposisi batuan asalnya sendiri, bukan akibat proses hidrotermal. UTJ pada kasus daerah Swakan lebih bersifat immobile, tidak mudah terlepas menjadi ion-ion dan diendapkan bersama zeolit, meskipun kehadirannya bersama pengendapan zeolit dimungkinkan karena zeolit memiliki kemampuan sebagai penukar kation (Duplouy, 2016).

Pola diagram laba-laba (spider diagram) unsur tanah jarang yang dinormalisasikan terhadap kondrit (McDonough and Sun, 1995) menunjukkan bahwa batuan vulkanik dari daerah Swakan memiliki pola unsur tanah jarang yang berbeda, tidak paralel atau berpotongan. Pola tersebut mengindikasikan bahwa sumber magma yang berbeda dan mengindikasikan proses magmatik yang berbeda. Menurut Sudjatmiko dan Santosa (1992), aktifitas magmatik tersebut paling tidak terjadi selama Pliosen Akhir. Dua buah sampel batupasir tufan daerah Cikembar menunjukkan pola diagram laba-laba paralel dan saling berhimpitan satu sama lain. Pola tersebut menunjukkan bahwa keduanya memiliki hubungan genetik (Wilson, 2007).

Pola diagram laba-laba batuan mengandung zeolit dari Swakan dan Cikembar dihasilkan pada zona subduksi, menghasilkan seri batuan calk-alkalin. Pola ini dicirikan oleh pengkayaan relatif UTJ ringan terhadap UTJ berat dan terdapat anomali negatif Eu (Gambar 8) (Wilson, 2007). Anomali Ce pada diagram laba-laba batupasir tufan Cikembar tidak ditemukan pada tuf Swakan 
(Gambar 8). Fenomena ini menunjukkan bahwa larutan yang berpengaruh terhadap pembentukkan zeolit adalah air meteorik (Terakado and Nakajima, 1995), fenomena ini juga teramati pada endapan zeolit Maze di Nigata, Jepang.

\section{KESIMPULAN}

Zeolit daerah Swakan (Bayah) dan Cikembar (Sukabumi) bertipe mordenit dan klinoptilolit. Zeolit Cikembar terbentuk pada batupasir tufan melalui proses diagenesa, sedangkan zeolit Swakan terbentuk pada tuf lapilli akibat proses hidrotermal.

Konsentrasi UTJ tidak berhubungan dengan pembentukkan zeolit. UTJ berhubungan dengan komposisi batuan induknya. Anomali negatif unsur Cerium pada batuan mengandung zeolit daerah Cikembar menunjukkan keterlibatan komponen air meteorik dalam pengendapan zeolit.

\section{UCAPAN TERIMAKASIH}

Terima kasih kepada Ibu Dewi Nurbaeti, Bapak Atet Saefulah, Bapak Jakah, dan Bapak Wawan Herawan, koordinator dan anggota Penelitian Prioritas Nasional (PN2), Pusat Penelitian Geoteknologi. Terima Kasih disampaikan juga kepada Reviewer dan Editor jurnal RISET, dan seluruh pihak yang telah membantu makalah ini dapat diterbitkan.

\section{DAFTAR PUSTAKA}

Connelly, Neil G., Richard M. Hartshorn, Ture Damhus, A. T. H. 2005. 'Nomenclature of Inorganic Chemistry: IUPAC Recomendations', Pure and Applied Chemistry, pp. 179-366. doi: 10.1515/ci.2005.27.6.25.

Coombs, D.S., Alberti, A., Armbruster, T. and Artiolli, G., 1997. Recommended nomenclature for zeolite minerals and de-odorase 11 for reducing odour and ammonia emissions from broiler houses. Vol. 35: 1571-1606. The Canadian Mineralogist.

Dempsey, S. R., 2013. Geochemistry of volcanic rocks from the Sunda Arc Geochemistry of volcanic rocks from the Sunda Arc. A thesis presented for the degree of Doctor of Philosophy, Department of earth Science, Durham University .
Dickson, J. S., 2015. Rare earth elements: Global market overview. In Simandl, G. J., Neetz, M. (eds.) Symposium on Strategic and Critical Materials Proceedings, November 13-14, 2015, Victoria, British Columbia. British Columbia Ministry of Energy and Mines, British Columbia Geological Survey Paper, Victoria, 5-11.

Duplouy, L., 2016. Preliminary Investigation of Rare Earth Elements Ion Exchange on Zeolites. Master thesis, University of Helsinki, Department of Chemistry, Laboratory of Radiochemistry

Effendi, A.C., 1974. Peta Geologi Lembar Bogor Skala 1:100.000. Pusat Penelitian dan Pengembangan Geologi, Bandung.

Estiaty, M.E., Fatimah, D., Marganingrum, D., Efendi, Setiawan, I., Lintjewas, L., Yuniati, M.D., Sumarnadi , E.T., Mulyono, A., Nurjayati, R., Rachmawati, V., Noviardi, R., 2018. Laporan Akhir Kegiatan Penelitian Pusat Penelitian Geoteknologi LIPI Tahun 2018. Pengembangan Teknologi Rekayasa Pengembangan Material Fungsional Berbasis Mineral dan Batubara (teknologi Mikroba Fngsional. Tidak dipublikasikan

Ghiara, M.R., Petti, C., Franco, E., Lonis, R., Luxoro, S. and Gnazzo, L., 1999. Occurrence of clinoptilolite and mordenite in Tertiary calc-alkaline pyroclastites from Sardinia (Italy). Clays and Clay Minerals, 47(3), pp.319-328.

Gottardi, G., 1989. The genesis of zeolites, Eur. J. Mineral, 1, pp. 479-487. doi: 10.1127/ejm/1/4/0479.

Gottardi, G. and Galli, E., 1985. Natural Zeolites. Springer-Verlag. New York, p.526

Hall, R., 2012. Late Jurassic-Cenozoic reconstructions of the Indonesian region and the Indian Ocean. Tectonophysics, 570, pp.1-41.

Hall, R., 1996. Reconstructing Cenozoic SE Asia, Geological Society, London, Special Publications, 106(1), pp. 153-184. doi: 10.1144/GSL.SP.1996.106.01.11. 
Holler, H. and Wirsching, U., 1978. Experiments on the formation of zeolites by hydrothermal alteration of volcanic glasses. In Natural Zeolites: Occurrence, Properties, Use; Sand, LB, Mumpton, FA Eds. pp 329-336.

Iijima, A., 1980. Geology of Natural Zeolites and Zeolitic Rocks, Printed in Great Britain. Plenary Paper-Geology and Mineralogy, 52, pp. 2-5. doi: 10.1103/PhysRevA.93.043821.

Kanazawa, Y. and Kamitani, M., 2006. Rare earth minerals and resources in the world. Journal of alloys and compounds, 408, pp.1339-1343.

Karakaya, M. Ç., Karakaya, N. and Yavuz, F. 2015. Geology and conditions of formation of the zeolite-bearing deposits southeast of Ankara (central Turkey), Clays and Clay Minerals, 63(2), pp. 85109. doi: 10.1346/CCMN.2015. 0630202.

Kartawa, W. and Kusumah, K.D., 2006. Potensi Zeolit di Daerah Sangkaropi-Mendila, Tana Toraja, Sulawesi Selatan. Jurnal Geologi dan Sumberdaya Mineral, 16(6), pp.371-386

Kitsopoulos, K. P., 1997. The genesis of a mordenite deposit by hydrothermal alteration of pyroclastics on Polyegos Island, Greece, Clays and Clay Minerals, 45(5), pp. 632-648. doi: 10.1346/CCMN.1997.0450503.

Kusdarto, 2008. Potensi zeolit di indonesia, Jurnal Zeolit Indonesia, 7(2), pp. 78-87.

McDonough, W. F. and Sun, S. s., 1995. The composition of the Earth, Chemical
Geology, 120(3-4), pp. 223-253. doi: 10.1016/0009-2541(94)00140-4.

Terakado, Y. and Nakajima, W., 1995. Characteristics of rare-earth elements, $\mathrm{Ba}, \mathrm{Sr}$ and $\mathrm{Rb}$ abundances in natural zeolites. Geochemical Journal, 29(6), pp.337-345.

Rodiana E.H., 2006. Potensi dan Pemanfaatan Zeolit di Provinsi Jawa Barat dan Banten, Buletin Sumberdaya Geologi. doi: 10.3724/SP.J.1041.2018.00953.

Rodiana, H.E. dan Permana, D., 2000, Eksplorasi lanjutan endapan zeolit di Kecamatan Cipatujah, Kabupaten Tasikmalaya, Jawa Barat. Direktorat Sumberdaya Mineral, Bandung.

Sanematsu, K., Kon, Y., Imai, A., Watanabe, K. and Watanabe, Y., 2013. Geochemical and mineralogical characteristics of ionadsorption type REE mineralization in Phuket, Thailand. Mineralium Deposita, 48(4), pp.437-451

Sujatmiko dan Santosa, S., 1992. Geologi Lembar Leuwidamar, Skala 1:100.000, Pusat Penelitian dan Pemetaan Geologi Bandung.

Vasylechko, V. O., Gryshchouk, G. V., Zakordonskiy, V. P., Patsay, I. O., Len, N. V., Len, N. V., Vyviurska, O. A., 2013. Sorption of terbium on Transcarpathian clinoptilolite, Microporous and Mesoporous Materials. Elsevier Inc., 167, pp. 155161. doi: 10.1016/j.micromeso.2012. 08.021 .

Wilson, M., 2007. Igneous Petrogenesis: A Global Tectonic Approach. Springer Science and Business Media. 